\title{
Videoconferencing for Home Care Delivery in Japan: Observational Study
}

Hirotomo Miyatake $^{1 *}, \mathrm{MD}$; Makoto Kosaka ${ }^{1,2^{*}}$; Satoshi Arita ${ }^{1}, \mathrm{MSc}$; Chie Tsunetoshi ${ }^{1}, \mathrm{BA}$; Hidehisa Masunaga ${ }^{1}$, MSc; Yasuhiro Kotera ${ }^{3}, \mathrm{PhD}$; Yoshitaka Nishikawa ${ }^{1}, \mathrm{MD}, \mathrm{PhD}$; Akihiko Ozaki ${ }^{1,4,5}, \mathrm{MD}, \mathrm{PhD}$; Hiroyuki Beniya ${ }^{1}$, MD

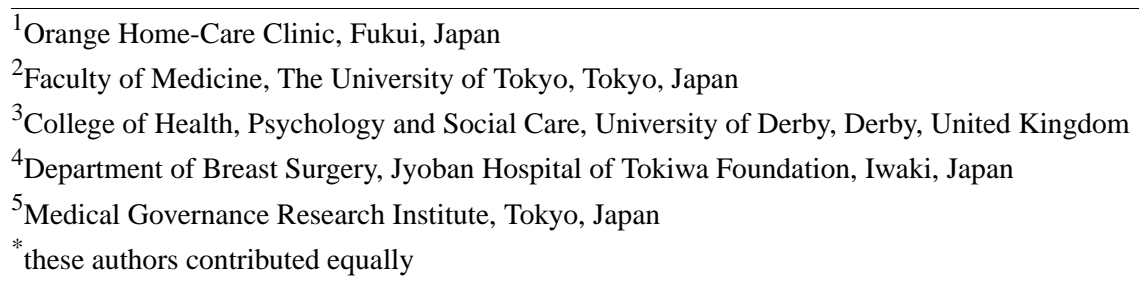

\section{Corresponding Author:}

Hirotomo Miyatake, MD

Orange Home-Care Clinic

Tawara 1-2-20, Fukui City

Fukui

Japan

Phone: 81776213333

Fax: 81776213353

Email: hmiyatake@ orangeclinic.jp

\section{Abstract}

Background: Telemedicine has been increasingly used in many health care fields, including home care, where patients receive medical care at home. Owing to the current COVID-19 crisis, the value of telemedicine via videoconferencing is more recognized, particularly in allowing immobile patients to continue receiving care. However, the efficacy of telemedicine in home care settings in Japan remains to be fully appraised.

Objective: This study aims to identify the use and impact of telemedicine in a singular home care delivery setting in Japan.

Methods: A retrospective observational study was conducted using patient and other administrative records from a home care clinic. We considered patients who were involved in videoconferencing with home care physicians and telepresenters serving patients during 2018 and 2019. We extracted sociodemographic data of the patients and details of the videoconferencing and descriptively illustrated some specific cases.

Results: In a home care clinic in Japan, videoconferencing was conducted in 17 cases (involving 14 patients) over a 2-year period. Of all the cases, $12 \%$ (2/17) required emergency transfers and were hospitalized. A total of $88 \%$ (15/17) of cases remained; $71 \%$ (12/17) of cases were found to need extra medication or to go to a medical facility for consultation, whereas $18 \%(3 / 17)$ of cases were found not to be in need of urgent attention and were asked to rest. Problematic symptoms subsequently improved in $82 \%(14 / 17)$ of cases, and only $6 \%(1 / 17)$ of cases were later hospitalized.

Conclusions: Telemedicine was deemed effective for assessing patients' conditions in the home care setting in situations where home visits by a physician cannot be carried out. Our findings indicate that consultations via videoconferencing are safe and effective, suggesting more active use of videoconferencing in other clinical contexts.

(J Med Internet Res 2021;23(9):e23539) doi: 10.2196/23539

\section{KEYWORDS}

telehome care; videoconference; home care; caregiver; telepresenter; mobile phone 


\section{Introduction}

\section{Background}

Telemedicine, the use of information and communication technology to deliver health care at a distance, has been increasingly used to deliver health care covering a wide range of specialties, for numerous conditions, and through a variety of channels and systems [1]. An ever-increasing body of evidence suggests that care delivered via telemedicine is safe and can be as, if not more, effective and economical as face-to-face care [1]. However, one review article pointed out that the effectiveness of telemedicine could depend on conditions and specialties, and evidence on its cost-effectiveness was limited [2]. In addition, it has been suggested that applications of telemedicine in home care should be cautiously conducted, holistically weighing various individual characteristics and external factors surrounding patients [3].

Moreover, significant barriers to wider use have been identified: health care providers and patients face regulatory ambiguities and financing uncertainties. Inequalities in both health and digital literacy are another concern, as patients who could benefit the most are often those who are the least able to have access to or make use of telemedicine [4]. Telemedicine has evolved to help improve effectiveness, efficiency, and equity in health care. However, it can also create risks, amplify existing inequalities, and worsen health care delivery.

Japan has been actively promoting telemedicine as a means to help meet the evolving health care needs of the population. Key areas of focus have been (1) access to health care for rural and remote communities, (2) home telemedicine, and (3) illness prevention and lifestyle modification. Evidence on the safety and efficacy of telemedicine in various situations has been presented at conferences [5]. The Japanese government has been encouraging telemedicine, especially as part of a strategy focusing on an effective home-based primary care approach, in an attempt to move away from the nation's famed lengthy hospitalization practice [6]. In 2015, Japan's Ministry of Health, Labor and Welfare (MHLW) permitted the use of telemedicine in areas other than rural and remote areas [7] and, in 2018, allowed medical treatment fees for remote examinations to be partially covered under the national health insurance scheme. However, provider-to-patient telemedicine services are only permitted after an initial face-to-face meeting has taken place between the physician and the patient [8]. It is the sole responsibility of the physician to decide whether remote health care is safe and appropriate.

\section{Objectives}

Only a few telemedicine studies in Japan have been published, mostly in the Japanese language, limiting the global reach of the findings [9]. An in-depth appraisal of the efficacy of telemedicine is particularly important in home care settings, as there are many factors that could prohibit physicians from physically visiting patients' homes immediately, beyond planned visits and in emergency situations. Telemedicine via videoconferencing is a possible means to help overcome this problem. However, its effectiveness and safety in assessing patients' conditions, including identifying potential acute illnesses and potential health emergencies, has not been evaluated in the home care setting in depth. Accordingly, the main goal of this study is to demonstrate some cases using videoconferencing and discuss its efficacy and safety and to identify some key elements in the home care setting in Japan.

\section{Methods}

\section{Overview of Japanese Health Insurance System, Home Care, and Remote Examination}

Home care in Japan is provided and paid for within the Japanese health insurance system. The Japanese government has promoted home care as a part of the Integrated Community Care System, which requires cooperation between home care providers [10] to reduce medical costs and overcome constraints, such as the number of physicians in Japan (2.5 per 1000 inhabitants), which is the lowest among the Organization for Economic Cooperation and Development countries [11].

\section{Integrated Community Care System}

The Integrated Community Care System, which is designed to provide medicine, nursing, and life support in an integrated format, has been developed to enable some patients, particularly older adults, to continue living at home in the manner to which they have become accustomed [10]. Home care is indicated only when the physician determines that it is applicable. There are no clear criteria, but patients who are at least unable to walk to the clinic on their own without the help of family members or caregivers is a requirement, and there are no age restrictions. Therefore, the patients involved in this research were those living in specialized housing facilities for older adults where a formal caregiver was available and those who were regularly visited by their physician, living in their own residences with the assistance of informal family caregivers.

\section{Cooperation Between Home Care Physicians and Nurses and Pharmacists}

In Japanese home care, patients receive nursing services from institutional nurses or visiting nurses under the medical insurance system or the long-term care insurance system. Some specialized caregiving facilities use full-time institutional nurses. Visiting nurses belong to clinics, hospitals, or nurse stations and provide physical and mental health services, including medical care and basic life support services. However, any physical intervention, such as management of intravenous injections or blood sampling, can only be administered under the supervision of the patient's physician. The clinic provides a visiting nurse service; however, it is up to patients whether they make use of the service.

In addition, pharmacies are counted as facilities that provide medical services in the Integrated Community Care System. Some pharmacies or clinics dispatch community pharmacists and provide indications for drug management to home care patients [11].

\section{Remote Examination in the Japanese Home Care Setting}

The MHLW has created strict definitions for what constitutes a remote examination, in which physicians deal with patients 
via a digital audiovisual link, such as via a videophone or the internet. Remote examinations were conducted in the same manner as face-to-face examinations. Until recently, the first examination must have been face-to-face; however, because of COVID-19, remote examination can now be used as the first examination session under certain conditions. As of April 2020, all physicians who intend to use videoconferencing are required to undertake training regulated by the MHLW.

Doctor to patient with nurse has been introduced as a common form of implementing remote examinations, in which a physician can see patients receiving home care via a digital audiovisual connection but only with a visiting nurse attending the patient. In this situation, visiting nurses are supposed to provide medical assistance within the range expected in the treatment plan and visiting nursing instruction. In this study, all remote examinations were conducted as a substitute for unplanned physician visits. Although doctor to patient without nurse is also permitted as a form of remote examination, most of the informal caregivers or patients involved in this study requested the presence of nurses.

In Japan, physicians are primarily responsible for any intervention, either directly or in an oversight capacity, conducted as part of any remote examination or intervention. If a physician determines that they are unable to perform an adequate remote examination, the physician must immediately discontinue the remote examination and arrange a face-to-face examination. Physicians are also required to take adequate security measures to ensure that patients' medical information is not compromised.

\section{Setting and Participants}

The Orange Home Care Clinic specializes in providing medical care to patients based on their own homes or residences in Fukui City, Japan. This clinic has five working teams, consisting of 1 physician and 1 clerk per team, treating an average of 330 patients annually. Several nurses have been employed to support the smooth operation of the clinic, such as coordination with other visiting nurse stations. Therefore, regular nursing care is provided by other visiting nurse stations. Each team visits 8-10 patients a day on weekdays. The visiting area covers a radius of $16 \mathrm{~km}$ from the clinic. Owing to various unforeseen circumstances (eg, natural disasters), the clinic used videoconferencing in 17 instances from January 2018 to December 2019.

\section{Data Collection}

Basic information on patients, such as age, sex, primary diseases, and availability of caregivers, was collected from medical records at the clinic. Data on cases where videoconferencing was used, such as the reason for the consultation, the telepresenter, any intervention, and the outcome, were collected from medical records and other documentation.

The availability of a caregiver was categorized as (1) formal caregiver (a patient living in a specialized housing facility where an official caregiver is present), (2) informal caregiver (patient living with a family member), and (3) no caregiver (a patient living alone). We used this classification because the feasibility of videoconferencing is supposed to depend on the living environment and the demographics in Japan have been changing rapidly, and the number of single-person households, especially among older adults, has been increasing significantly [12].

In this study, videoconferencing was performed when a caregiver or a visiting nurse decided that it was necessary to consult with a physician when visiting the patient. Videoconferencing was performed as an alternative to an emergency home visit because the physician could not visit immediately. The reason for videoconferencing consultation involved the chief complaint when a consultation was requested by the patient or caregiver. The telepresenter was the person with the patient who orchestrated the remote videoconferencing connection with the physician. Telepresenters need to have adequate knowledge and skill with respect to information technology devices and a proper understanding of the patient's status. They can be informal caregivers, formal caregivers, and visiting nurses; however, we defined the telepresenter as no one when the patients facilitated videoconferencing by themselves. The intervention referred to any medical procedure, which was determined to be necessary during videoconferencing and before the next planned visit could be undertaken. Although the options of interventions depend on the presence of nurses with patients, interventions such as applying drugs to patients are applicable even if patients contact the physician by themselves. The outcome was categorized as (1) symptom improvement when the patients did not need additional treatment by physicians other than intervention decided through videoconferencing, (2) patients required another unplanned visit by a home care physician before the next planned visit, or (3) patients required hospitalization (when the patient was hospitalized after videoconferencing).

\section{Ethical Review}

This study adheres to the Ethical Guidelines for Medical and Health Research Involving Human Subjects and meets Japan's local legal requirements. Study approval was granted by the Ethics Committee of the Medical Governance Research Institute on June 4, 2020 (MG2018-18-20200604).

\section{Results}

\section{Participant Statistics}

Table 1 shows a summary of all the cases included in this study. 
Table 1. Sociodemographic details of the patients and videoconference information.

\begin{tabular}{|c|c|c|c|c|c|c|c|c|c|}
\hline ID & $\begin{array}{l}\text { Age } \\
\text { (years) }\end{array}$ & Sex & Primary disease & $\begin{array}{l}\text { Availability } \\
\text { of caregiver }\end{array}$ & $\begin{array}{l}\text { Reasons for remote } \\
\text { consultation }\end{array}$ & Telepresenter & Diagnosis & Intervention & Outcome \\
\hline $1-1$ & 97 & Female & Stomach cancer & $\begin{array}{l}\text { Formal } \\
\text { caregiver }\end{array}$ & Fall & Visiting nurse & $\begin{array}{l}\text { Suspect of } \\
\text { bone fracture }\end{array}$ & $\begin{array}{l}\text { Prescription of } \\
\text { pain reliever }\end{array}$ & $\begin{array}{l}\text { Symptom } \\
\text { improvement }\end{array}$ \\
\hline $1-2$ & 97 & Female & Stomach cancer & $\begin{array}{l}\text { Formal } \\
\text { caregiver }\end{array}$ & Phlegm & Visiting nurse & $\begin{array}{l}\text { Bacterial } \\
\text { infection }\end{array}$ & $\begin{array}{l}\text { Prescription of } \\
\text { antibiotics }\end{array}$ & $\begin{array}{l}\text { Symptom } \\
\text { improvement }\end{array}$ \\
\hline 2 & 92 & Female & Dementia & $\begin{array}{l}\text { Formal } \\
\text { caregiver }\end{array}$ & Vomiting & Visiting nurse & Gastroenteritis & $\begin{array}{l}\text { Prescription of } \\
\text { antiemetic } \\
\text { drug }\end{array}$ & $\begin{array}{l}\text { Symptom } \\
\text { improvement }\end{array}$ \\
\hline 3 & 93 & Male & Dementia & $\begin{array}{l}\text { Informal } \\
\text { caregiver }\end{array}$ & Scratch & Visiting nurse & Eczema & $\begin{array}{l}\text { Applying } \\
\text { ointment }\end{array}$ & $\begin{array}{l}\text { Symptom } \\
\text { improvement }\end{array}$ \\
\hline 4 & 70 & Female & $\begin{array}{l}\text { Last stage of } \\
\text { stomach cancer }\end{array}$ & $\begin{array}{l}\text { Informal } \\
\text { caregiver }\end{array}$ & Headache & Visiting nurse & $\begin{array}{l}\text { Muscle con- } \\
\text { traction } \\
\text { headache }\end{array}$ & $\begin{array}{l}\text { Treatment in } \\
\text { acupuncture } \\
\text { clinic }\end{array}$ & $\begin{array}{l}\text { Symptom } \\
\text { improvement }\end{array}$ \\
\hline 5 & 66 & Female & $\begin{array}{l}\text { Last stage of lung } \\
\text { cancer }\end{array}$ & $\begin{array}{l}\text { Informal } \\
\text { caregiver }\end{array}$ & $\begin{array}{l}\text { Uncomfortable } \\
\text { feeling }\end{array}$ & Visiting nurse & Dehydration & Infusion & $\begin{array}{l}\text { Symptom } \\
\text { improvement }\end{array}$ \\
\hline 6 & 35 & Male & $\begin{array}{l}\text { Cerebral } \\
\text { contusion }\end{array}$ & $\begin{array}{l}\text { Informal } \\
\text { caregiver }\end{array}$ & $\begin{array}{l}\text { Suspect of drug } \\
\text { eruption }\end{array}$ & Visiting nurse & Drug eruption & $\begin{array}{l}\text { Stopping } \\
\text { antibiotics }\end{array}$ & $\begin{array}{l}\text { Symptom } \\
\text { improvement }\end{array}$ \\
\hline 7 & 33 & Male & $\begin{array}{l}\text { Acquired cerebral } \\
\text { palsy }\end{array}$ & $\begin{array}{l}\text { Informal } \\
\text { caregiver }\end{array}$ & $\begin{array}{l}\text { Suspect of low- } \\
\text { temperature burn }\end{array}$ & $\begin{array}{l}\text { Informal } \\
\text { caregiver }\end{array}$ & $\begin{array}{l}\text { Low-tempera- } \\
\text { ture burn }\end{array}$ & $\begin{array}{l}\text { Applying } \\
\text { ointment }\end{array}$ & $\begin{array}{l}\text { Symptom } \\
\text { improvement }\end{array}$ \\
\hline 8 & 16 & Male & $\begin{array}{l}\text { Neurofibromato- } \\
\text { sis type } 1\end{array}$ & $\begin{array}{l}\text { Informal } \\
\text { caregiver }\end{array}$ & Fever & Visiting nurse & $\begin{array}{l}\text { Acute bronchi- } \\
\text { tis }\end{array}$ & $\begin{array}{l}\text { Prescription of } \\
\text { antibiotics }\end{array}$ & $\begin{array}{l}\text { Symptom } \\
\text { improvement }\end{array}$ \\
\hline 9 & 11 & Male & West syndrome & $\begin{array}{l}\text { Informal } \\
\text { caregiver }\end{array}$ & Epileptic seizures & $\begin{array}{l}\text { Institutional } \\
\text { nurse }\end{array}$ & $\begin{array}{l}\text { Epileptic } \\
\text { seizures }\end{array}$ & $\begin{array}{l}\text { Watch and } \\
\text { wait }\end{array}$ & $\begin{array}{l}\text { Symptom } \\
\text { improvement }\end{array}$ \\
\hline 10 & 7 & Male & Cerebral palsy & $\begin{array}{l}\text { Informal } \\
\text { caregiver }\end{array}$ & $\begin{array}{l}\text { Swelling of the } \\
\text { eyelid }\end{array}$ & $\begin{array}{l}\text { Institutional } \\
\text { nurse }\end{array}$ & Hordeolum & $\begin{array}{l}\text { Prescription of } \\
\text { eye-drops }\end{array}$ & $\begin{array}{l}\text { Symptom } \\
\text { improvement }\end{array}$ \\
\hline $11-1$ & 4 & Female & $\begin{array}{l}\text { Double outlet } \\
\text { right ventricle }\end{array}$ & $\begin{array}{l}\text { Informal } \\
\text { caregiver }\end{array}$ & $\begin{array}{l}\text { Suspect of } \mathrm{CV}^{\mathrm{a}} \\
\text { block }\end{array}$ & Visiting nurse & CV block & $\begin{array}{l}\text { Emergency } \\
\text { transfer }\end{array}$ & $\begin{array}{l}\text { Hospitaliza- } \\
\text { tion }\end{array}$ \\
\hline $11-2$ & 4 & Female & $\begin{array}{l}\text { Double outlet } \\
\text { right ventricle }\end{array}$ & $\begin{array}{l}\text { Informal } \\
\text { caregiver }\end{array}$ & $\begin{array}{l}\text { Vomiting and } \\
\text { diarrhea }\end{array}$ & Visiting nurse & Dehydration & $\begin{array}{l}\text { Emergency } \\
\text { transfer }\end{array}$ & $\begin{array}{l}\text { Hospitaliza- } \\
\text { tion }\end{array}$ \\
\hline 12 & 3 & Female & Lissencephaly & $\begin{array}{l}\text { Informal } \\
\text { caregiver }\end{array}$ & Tachycardia & Visiting nurse & None & $\begin{array}{l}\text { Watch and } \\
\text { wait }\end{array}$ & $\begin{array}{l}\text { Symptom } \\
\text { improvement }\end{array}$ \\
\hline $13-1$ & 2 & Male & Cerebral palsy & $\begin{array}{l}\text { Informal } \\
\text { caregiver }\end{array}$ & Increase of phlegm & $\begin{array}{l}\text { Informal } \\
\text { caregiver }\end{array}$ & $\begin{array}{l}\text { Upper respira- } \\
\text { tory inflamma- } \\
\text { tion }\end{array}$ & $\begin{array}{l}\text { Watch and } \\
\text { wait }\end{array}$ & $\begin{array}{l}\text { Symptom } \\
\text { improvement }\end{array}$ \\
\hline $13-2$ & 2 & Male & Cerebral palsy & $\begin{array}{l}\text { Informal } \\
\text { caregiver }\end{array}$ & Fever & Visiting nurse & $\begin{array}{l}\text { Middle ear in- } \\
\text { flammation }\end{array}$ & $\begin{array}{l}\text { Continuing } \\
\text { antibiotics }\end{array}$ & $\begin{array}{l}\text { Hospitaliza- } \\
\text { tion }\end{array}$ \\
\hline 14 & 72 & Female & $\begin{array}{l}\text { Rheumatoid } \\
\text { arthritis }\end{array}$ & No caregiver & Eczema & Visiting nurse & Miliaria & $\begin{array}{l}\text { Prescription } \\
\text { of ointment }\end{array}$ & $\begin{array}{l}\text { Symptom } \\
\text { improvement }\end{array}$ \\
\hline
\end{tabular}

${ }^{\mathrm{a}} \mathrm{CV}$ : cardiovascular.

Remote videoconferencing was conducted in 17 instances involving 14 patients (3 patients were involved in videoconferencing twice). Of the 14 patients, $5(36 \%)$ were children and $5(36 \%)$ were older adults (aged $>65$ years). Approximately $43 \%$ (6/14) of patients were male. According to the International Classification of Diseases 11th categorization, the most common primary disease was that of the nervous system $(5 / 14,36 \%)$, followed by neoplasms $(3 / 14$, $21 \%$ ) and mental, behavioral, or neurodevelopmental disorders $(2 / 14,14 \%)$. About $79 \%(11 / 14)$ of patients lived with family members, 14\% (2/14) lived in assisted-living facilities, and 7\% (1/14) lived alone.

The reasons for videoconferencing consultation and diagnoses are shown in Table 1. In 77\% (13/17) of instances, visiting nurses coordinated the videoconferencing, whereas, in $12 \%$ $(2 / 17)$ of instances, institutional nurses performed that task. In $12 \%(2 / 17)$ of instances, an informal caregiver handled the videoconferencing. 
As for subsequent interventions, a new prescription for medicine followed in $35 \%$ (6/17) of videoconferences; the physician faxed the prescription to the community pharmacist, and the community pharmacist delivered the new medicine to the patients' residences. In 18\% (3/17) of instances, watch and wait until the next planned visit instructions and the guidance on the application of medicine were given. In 12\% (2/17) of instances, the physician instructed patients to take the medicine in hand. In contrast, in $12 \%(2 / 17)$ of instances, emergency transfer to hospital was advised; the physician arranged the emergency transfers and passed the patient information to the attending physicians in the hospital who provided emergency treatment.

With regard to outcomes, $82 \%$ (14/17) of cases with the use of videoconferencing resulted in improvement of the problematic symptoms before the next planned visit was conducted within the following 2 weeks, and the remaining 18\% (3/17) of cases resulted in hospitalization. One hospitalization was because of pneumonia from an upper respiratory infection that occurred independently after the videoconferencing had taken place.

In ID 1-2, although a formal caregiver was available, albeit a part-time worker, the clinic was called, and the physician asked a visiting nurse to visit the patient's residence as the physician was not able to visit the residence immediately. The visiting nurse subsequently organized and conducted the videoconferencing. In IDs 6 and 8, an informal caregiver was available, and he or she summoned a visiting nurse who organized and conducted the videoconferencing. In ID 7, an informal caregiver was available and organized and conducted the videoconferencing.

\section{Indicative Videoconferencing Examples}

\section{ID Number 1-2}

The patient was a 97-year-old female with early-stage gastric cancer and chronic heart failure. She lived in a long-term facility with no full-time nurses in attendance but with part-time nurses, with nonmedical informal caregiver helpers providing various care services to the residents. The patient was able to walk using a walker and take a bath with the support of helpers. As she was unable to visit the clinic by herself because of lower-extremity muscle weakness and as her gastric cancer was relatively stable, her medical home care started in February 2015, and the team visited her twice monthly. She wished to spend the rest of her life in the facility. One night in October 2018, the facility's part-time nurse contacted us as the patient had an approximate 2-week history of excess phlegm and breathlessness. The last regular visit by a home care physician was 12 days previously when she had a hoarse voice and was taking regular herbal medicine, as she presumed that she had caught a cold. She was able to eat and did not feel seriously ill; therefore, a home care physician decided to follow up and told her to contact the clinic if her condition worsened. Her body temperature was $37.3^{\circ} \mathrm{C}$, blood pressure was $155 / 92 \mathrm{~mm} \mathrm{Hg}$, pulse rate was $80 \mathrm{bpm}$, saturation of percutaneous oxygen was $94 \%$, and the state of consciousness was clear. Although a home care physician attempted to visit the facility, the physician was not able to do so immediately. Therefore, the physician ordered a visiting nurse from the clinic to visit the patient's facility and instead carried out a videoconferencing. The nurse told the physician that there were no obvious lung noises, which suggested that pneumonia was not present, and her body movement, such as standing and sitting, was smooth. The physician carefully observed the patient's complexion and respiratory status through videoconferencing and reconciled the findings with those reported by the nurse. As a result of the videoconferencing examination, the physician ordered the nurse to take a blood test to judge whether there was an acute bacterial respiratory infection and deterioration of chronic heart failure. The nurse returned the blood sample to the clinic and submitted it for testing. The blood test indicated that the white blood cell (WBC) count was 5180 per $\mu \mathrm{L}$ and C-reactive protein (CRP) was 0.12 $\mathrm{mg} / \mathrm{dL}$, and the physician diagnosed an acute viral respiratory infection based on the results of the blood test. The physician prescribed a traditional Chinese medicine to reduce her symptoms and then faxed the prescription to a specific pharmacy. The community pharmacist delivered the drug to the patient's assisted-living facility and started the treatment with the traditional Chinese medicine (syoseiryuutou $9 \mathrm{~g} 3$ times a day for 5 days). Two days later, the physician confirmed an increase in $\mathrm{N}$-terminal probrain natriuretic peptide from the blood test taken by the visiting nurse, and the deterioration of chronic heart failure was diagnosed, and the treatment with a diuretic drug (furosemide $20 \mathrm{mg}$ once per day for 7 days) was started. The community pharmacist contacted the patient, delivered the drug to the facility, and administered the first dose. In this case, the nurse being physically present with the patient during the remote examination allowed blood tests to be completed, which allowed the diagnosis of an acute viral respiratory infection and deterioration of the patient's cardiac problem, thereby allowing early and customized treatment.

\section{ID Number 8}

The patient was a 16-year-old male with neurofibromatosis type 1. He had a gastrostomy to be fed and underwent noninvasive positive pressure ventilation every night. He spent most of the daytime using a wheelchair and lived in his house with the support of his parents. His twice-monthly home care started in February 2011 to help reduce the burden on his family, who previously had to frequently visit emergency medical departments because of his regular fevers. One morning in September 2018, the patient's family reported by telephone that the patient had a fever of $37.8^{\circ} \mathrm{C}$ with excess phlegm; however, his respiratory condition was not troublesome. As the condition was not serious but needed careful monitoring, the physician told the family to observe with an antipyretic drug and water intake. In addition, the physician ordered a visiting nurse to visit the patient's residence to check the patient's condition, as he had acute viral bronchitis with bacterial secondary infection and was treated with an antibiotic 1 month before this consultation. When the visiting nurse visited the patient's residence that afternoon, his temperature was $37.8^{\circ} \mathrm{C}$, although an antipyretic drug had been administered by his informal caregivers approximately 3 hours previously, and thus, the nurse decided to conduct a videoconferencing. The patient's condition was similar to that of acute bronchitis that he had experienced 1 month before, which had been resolved following a visit by the team 2 weeks earlier. Therefore, the physician diagnosed acute viral bronchitis with bacterial secondary infection based 
on the clinical symptoms and the patient's past history and prescribed a course of antibiotics-sultamicillin tosylate dihydrate $9 \mathrm{~g}$ after every meal for 7 days. The prescription was faxed to a specialized pharmacy, and the patient's mother went to the pharmacy to get the medication and administered it as per instructions. In the meantime, the visiting nurse kept an eye on the patient. The physician performed an emergency home visit 2 days later because the patient's mother called the clinic as the fever continued. At that visit, as the physician suspected pneumonia, the physician performed a sputum test and a blood test to decide whether his antibiotic drug had to be changed. The results of the laboratory test showed a WBC count of 9410 per $\mu \mathrm{L}$ and CRP of $3.14 \mathrm{mg} / \mathrm{dL}$. The physician judged that his infection was getting past the acute stage as the CRP level was mildly elevated; however, the WBC and other data were within normal limits. The physician decided not to change the antibiotic and finish the 7-day treatment because adolescents with special care needs are prone to viral infections and secondary bacterial infections, and the infections are often severe. The patient's condition improved 1 week later, and a new bacterial culture of sputum did not reveal any infection. In this case, remote medical examination was useful to diagnose possible acute viral bronchitis with bacterial secondary infection based on the patient's past history, and action could be taken to respond to the new infection.

\section{ID Number 6}

The patient was a 35-year-old bedridden male patient who had a postoperative left acute subdural hematoma caused by a traffic accident. He had undergone a number of medical procedures, including a tracheostomy, 2 gastrointestinal stomata, a gastronomy, and insertion of a ventral venous catheter. The two gastrointestinal stomata were used to drain intestinal fluids because he developed nonocclusive mesenteric ischemia and had most of his intestinal tract removed in 2017. For that reason, he underwent a gastrostomy and used a central venous catheter to obtain nutrition. His parents provided his daily care, and home-visiting nurses made two regular visits and provided regular medical attention daily. The clinic also provided weekly medical home care from March 2018. In April 2018, the visiting nurse telephoned the clinic to report that the patient had had fever for a few days, and the physician told the nurse to take blood for testing. From the results-increased WBC $(10,210$ per $\mu \mathrm{L}$ with a left shift) and CRP $(5.65 \mathrm{mg} / \mathrm{dL})$ — the patient was assessed to have an acute bacterial infection. The clinic staff brought sulbactam sodium and ampicillin sodium from the clinic's stocks to the patient's residence, and the physician told the nurse to administer it during regular morning and evening visits because there was no allergic information about the patient from the referral hospital. A few minutes after the intravenous injection of the antibiotic, eczema appeared on the patient's chest, indicating an allergic reaction. Therefore, a remote visual medical examination was conducted to check the patient's condition. No other abnormal findings were observed, such as respiratory distress or decrease in saturation of percutaneous oxygen, and the eczema disappeared 30 minutes after the intravenous injection. The suspected allergic reaction reminded the patient's father of the patient's previous history of suspected allergic reactions, and he reported that the same reaction was observed when the patient was hospitalized and that most of the antibiotics gave the patient redness. As the referral from the hospital stated that the patient had no allergies, the home care physician contacted the hospital; however, there was no information about redness in the hospital records. Thus, they discontinued sulbactam sodium and ampicillin sodium because these drugs were suspected as allergens and instead initiated ceftriaxone sodium hydrate. As such, the remote medical examination was useful for diagnosing possible allergic reactions and helped to change the antibiotics being administered.

\section{ID Number 7}

A 33-year-old male patient was bedridden because of cerebral palsy and had undergone a gastrostomy. The twice-monthly home care service started in December 2014 because the patient's family had to regularly take him to a hospital because he was regularly developing a fever. In December 2018, the family called the clinic to report that there was redness in the joints of his left hand, which seemed to be a low-temperature burn. The physician made a remote visual examination using the family's mobile phone to ascertain whether a home visit was required to deal with the situation. In discussion with the family, the physician confirmed that the red lesion appeared after using a hot-water bottle to keep the body warm. His left hand had been in prolonged contact with the hot-water bottle; however, there was no pain, only redness. Therefore, the physician decided to treat the scald using steroid ointment, which was originally prescribed to be applied to the granulation around the gastrostomy and so was available at the patient's home, and told the family to contact the clinic if there was any worsening of the patient's condition. After 2 weeks, the scald healed at the time of the next regular visit. Remote medical treatment was useful to diagnose a low-temperature burn and start treatment immediately without the need for a visiting nurse.

\section{Discussion}

\section{Principal Findings}

Treatments following videoconferencing in the clinic were generally safe and effective. As shown in Table 1, for $77 \%$ (13/17) of cases, the problematic symptom causing the need for a videoconferencing improved without emergency transfer or treatment in a medical facility. No intervention by medical professionals was required in $29 \%$ (5/17) of instances. The use of videoconferencing was deemed effective for physicians to reduce unnecessary visits, whereas in some cases, more nurse visits were required.

One key element for the successful use of videoconferencing was collaboration between medical staff in the prevailing situation. In Japan, specialized home medical care is overseen by physicians in specialized home care clinics. Other medical staff, such as visiting nurses, community pharmacists, and rehabilitation staff, work in a system whereby the corps of local visiting medical specialists provide more regular home care. A shared notebook stored in the patient's residence is used to update all clinical information for use by medical professionals involved in the provision of care to coordinate their work and actions. In addition, when medical staff detect any significant adverse signs in the patient's physical condition while visiting 
residences, they arrange a teleconference with other medical staff, including physicians, immediately. The videoconferencing enabled visiting nurses to implement prompt blood tests necessary for diagnosis and treatment and subsequently facilitate a physician's judgment in any necessity for intervention to deal with the patients' condition. In fact, Funderskov et al [13] showed that the use of video consultation allows community-based nurses to discuss their observations, enabling them to take part in active home care, including palliative care. A comparison of our findings with those in other countries is difficult because of the Japanese health context, where physicians predominantly have governing control in patients' care. However, in home care and remote examination, physicians have to rely on the judgments and actions of other medical staff to implement timely and appropriate medical interventions.

Videoconferencing allows the analysis of outward appearance of signs and symptoms. Interviews with patients and clinicians in previous studies showed that video consulting was better than telephone consulting, especially in consultations involving psychological assessment where visual cues are important, as illustrated by the cases of IDs 1-2 in this study [14]. With regard to the feasibility and accuracy of diagnosing through videoconferencing, according to a review by Trettel et al [15], most of the articles on teledermatology reported that telemedicine was feasible, reliable, and effective under various conditions. Furthermore, the review noted that in $90.3 \%$ of the cases, clinicians rated that the experience of conducting a telehealth session was equivalent to or better than a home visit and that the communication environment (eg, internet reception) was the important factor in telehealth sessions [16]. Japan has a reliable digital communication system: in our cases, all the videoconferencing with the patient's homes was done using $4 \mathrm{G}$ connections, and the communication channel was never interrupted or lost.

However, there are several critical points that need to be considered with respect to incorporating telemedicine in the home care setting. First, the telepresenter, the person who organizes the videoconferencing in the patient's location, is critical. It is ideal that the main caregivers, including informal caregivers, are able to orchestrate videoconferencing, although this might be a heavy burden for informal caregivers. Clinically, telepresenters are chosen considering their availability, ability, and digital literacy. Future research is expected to clarify whether informal caregivers can play the role of telepresenters appropriately and what kind of support or intervention is required to overcome this problem. Furthermore, in addition to medical literacy, the availability of suitable equipment, technological literacy of patients, their caregivers, attendant nursing staff, and attending physicians, as well as costs, have to be taken into account. A study of telemedicine between nurses and patients at home in Norway highlighted the importance of the levels of training and experience with respect to videoconferencing [17]. In particular, older people are not accustomed to using digital devices, and many do not even own or have access to computers or sophisticated mobile phones. According to Japan's Ministry of Internal Affairs and Communications, the proportion of internet users in the country is approximately $20 \%$ in those aged $>80$ years, whereas it is
$>90 \%$ in people aged 20-40 years [18]. It might be helpful to instruct all home care caregivers or nurses on how to use communication devices in telemedicine. A previous study recommended supporting digital literacy and confidence of older people to strengthen their intention to use technology [19]. Considering the increase in the number of older patients who live alone in Japan, developing digital skills among older adults is also beneficial to create more space in the limited caregiving facilities. Therefore, policies may have to be put in place to accommodate the provision of medical home care to older patients who live alone.

Second, the cost of communication devices should be considered. Some patients do not have any equipment enabling videoconferencing, which poses significant constraints on developing a videoconferencing telemedicine system. This endangers one of the primary aims of videoconferencing implementation - equity. In fact, the Ministry of Internal Affairs and Communications reported that the internet use rate in Japan was $>54.2 \%$ in households, with an annual income of <¥2 million ( $<$ US $\$ 19,000)$, whereas it was $>85 \%$ in households with > $¥ 4$ million (>US $\$ 38,000$ ) [20]. The cost of internet use depends on the type of service used. For example, in cases of our study, because the smartphones of patients, family caregivers, or clinics were used in videoconferencing, no additional cost other than communication costs paid by patients was needed. Commonly in Japan, medical institutions use remote examination platforms or phone calls when conducting remote examinations [21]. However, it is uncommon that the Japanese national insurance system covers the cost of provision of adequate devices, training in their use, the videoconferencing connection, and the administration of setting up videoconferencing. It is important to encourage patients or caregivers to, wherever and whenever possible, be able to use modern communication equipment, enabling them to use videoconferencing or telemedicine in times of emergency or whenever a physician is unable to make a physical visit. Another option is to change the system so that nurses and paramedics can conduct medical interventions without referring to physicians.

Third, telemedicine may miss some important clinical information that could be obtained in a face-to-face consultation. In addition, orchestrating sample collection, transport for testing, and analyses also takes longer than it would in a hospital or clinic environment, and the inability to use specialized equipment to aid diagnoses, which would often be available in medical facilities, makes home care less than ideal. Of note, we should be aware that the use of telemedicine in emergency cases in a home care setting is still in its infancy, and a careful and gradual evolution is imperative. It is essential for physicians and other health care professionals to perform a follow-up, in-person evaluation following any telemedicine event, as is currently done. It is also important to err on the side of caution when carrying out emergency telemedical consultations by calling for emergency transfers in cases possibly requiring rapid interventions or access to specialized physicians, facilities, or equipment. 


\section{Limitations}

The sample size of this study was small and diverse, and the study findings should be interpreted with caution. We could not compare the difference in the feasibility of conducting videoconferencing, depending on the living environment; however, formal caregivers may facilitate videoconferencing better because of their knowledge and experience of using videoconferencing. Moreover, considering the increase in older patients who live alone in Japan, the costs involved, and the scarcity of suitable accommodation, it is difficult for them to move into caregiving facilities. Therefore, new strategies and policies should be developed to ensure the provision of a suitable level of care as Japan moves toward increased provision of home care for patients.

Owing to the notification from the MHLW concerning remote examination, it is expected for videoconferencing in home care to increase in Japan in the foreseeable future. Troubles may manifest when considerably more examinations are conducted at the same time. In particular, as we discussed, the age of patients and caregivers can affect the use of videoconferencing, as observed in this study. Future research should be conducted with larger sample sizes to examine the reliability of our findings through stratified analyses.

\section{Conclusions}

Consultations using videoconferencing in clinics are generally safe and effective. Telemedicine is a valuable substitute for face-to-face investigations where necessary or desirable. This is a particularly valuable option in emergency situations, especially when home care health personnel cannot access the patients under their care. Japan has recently introduced the concept of primary care and has introduced training and qualifications in primary care. This will have a major impact on home care options and practice, and the importance of and potential for videoconferencing will be further enhanced accordingly. Furthermore, the findings of our study have special implications in the COVID-19 era. Considering the vast and long-lasting impacts of the current global COVID-19 pandemic, where physical visits are restricted, the findings in this study can help health care workers, patients, and their families involved in home care to appraise the characteristics of this relatively new approach.

\section{Acknowledgments}

The authors express their sincere gratitude to all the clinic staff members, patients, and caregivers involved in this study. They would like to thank Professor Andy Crump for his expertise and guidance in the production of this paper. This research was supported by Yuumi Memorial Foundation for Home Health Care.

\section{Authors' Contributions}

HM and MK analyzed the data and wrote the manuscript. All authors conceptualized and designed the study and revised the manuscript.

\section{Conflicts of Interest}

AO received a personal fee from MNES Inc, outside the submitted work. YN received a personal fee from MRT Inc, outside the submitted work.

\section{References}

1. Hashiguchi TC. Bringing health care to the patient: an overview of the use of telemedicine in OECD countries. In: OECD Health Working Papers. Paris: OECD Publishing; 2020.

2. Eze ND, Mateus C, Hashiguchi TC. Telemedicine in the OECD: an umbrella review of clinical and cost-effectiveness, patient experience and implementation. PLoS One 2020 Aug 13;15(8):e0237585 [FREE Full text] [doi: 10.1371/journal.pone.0237585] [Medline: 32790752]

3. Shigekawa E, Fix M, Corbett G, Roby DH, Coffman J. The current state of telehealth evidence: a rapid review. Health Aff (Millwood) 2018 Dec;37(12):1975-1982. [doi: 10.1377/hlthaff.2018.05132] [Medline: 30633674]

4. Latulippe K, Hamel C, Giroux D. Social health inequalities and eHealth: a literature review with qualitative synthesis of theoretical and empirical studies. J Med Internet Res 2017 Apr 27;19(4):e136 [FREE Full text] [doi: 10.2196/jmir.6731] [Medline: 28450271]

5. Japanese Journal of Telemedicine and Telecare Vol 15 Supplement (Japanese). Japanese Telemedicine and Telecare Association. 2020. URL: https://plaza.umin.ac.jp/ jtta/pdf/book/vol15no3.pdf [accessed 2021-08-23]

6. [Telemedicine in Japan 2013]. Japanese Telemedicine and Telecare Association. URL: http://jtta.umin.jp/pdf/telemedicine/ telemedicine in japan 20131015-2 jp.pdf [accessed 2020-10-06]

7. [About examination using internet communication devices]. Ministry of Health, Labour and Welfare of Japan. URL: https:/ /www.mhlw.go.jp/file/06-Seisakujouhou-10800000-Iseikyoku/0000094452.pdf [accessed 2020-08-06]

8. [Guidelines for appropriate online examination practice]. The Ministry of Health, Labour and Welfare, Japan. URL: https:/ /www.mhlw.go.jp/content/000534254.pdf [accessed 2020-08-06]

9. Ito J, Edirippulige S, Aono T, Armfield NR. The use of telemedicine for delivering healthcare in Japan: systematic review of literature published in Japanese and English languages. J Telemed Telecare 2017 Dec;23(10):828-834. [doi: 10.1177/1357633X17732801] [Medline: 29081269] 
10. [Integrated community care system]. The Ministry of Health, Labour and Welfare, Japan. URL: https://www.mhlw.go.jp/ stf/seisakunitsuite/bunya/hukushi kaigo/kaigo koureisha/chiiki-houkatsu/ [accessed 2020-07-23]

11. Onda M, Imai H, Nanaumi Y, Hirano A, Fujii S, Arakawa Y. [Nationwide study on relations between workload and outcomes of home visiting service by community pharmacists]. Yakugaku Zasshi 2015;135(3):519-527 [FREE Full text] [doi: 10.1248/yakushi.14-00220] [Medline: 25759060]

12. [Housing for the elderly]. The Ministry of Health, Labour and Welfare, Japan. URL: https://www.mhlw.go.jp/seisaku/2009/ 03/01.html [accessed 2020-10-06]

13. Funderskov KF, Danbjørg DB, Jess M, Munk L, Zwisler AO, Dieperink KB. Telemedicine in specialised palliative care: healthcare professionals' and their perspectives on video consultations-a qualitative study. J Clin Nurs 2019 Nov;28(21-22):3966-3976. [doi: 10.1111/jocn.15004] [Medline: 31328336]

14. Hammersley V, Donaghy E, Parker R, McNeilly H, Atherton H, Bikker A, et al. Comparing the content and quality of video, telephone, and face-to-face consultations: a non-randomised, quasi-experimental, exploratory study in UK primary care. Br J Gen Pract 2019 Aug;69(686):595-604 [FREE Full text] [doi: 10.3399/bjgp19X704573] [Medline: 31262846]

15. Trettel A, Eissing L, Augustin M. Telemedicine in dermatology: findings and experiences worldwide - a systematic literature review. J Eur Acad Dermatol Venereol 2018 Feb;32(2):215-224. [doi: 10.1111/jdv.14341] [Medline: 28516492]

16. Taylor A, Morris G, Pech J, Rechter S, Carati C, Kidd M. Home telehealth video conferencing: perceptions and performance. JMIR Mhealth Uhealth 2015 Sep 17;3(3):e90-e9- [FREE Full text] [doi: 10.2196/mhealth.4666] [Medline: 26381104]

17. Rygg L, Brataas H, Nordtug B. Introducing videoconferencing on tablet computers in nurse-patient communication: technical and training challenges. Int J Telemed Appl 2018;2018:8943960 [FREE Full text] [doi: 10.1155/2018/8943960] [Medline: 30420881]

18. [White paper information and communications in Japan]. The Ministry of Internal Affairs and Communications, Japan. URL: https://www.soumu.go.jp/johotsusintokei/whitepaper/ja/h30/html/nd142110.html [accessed 2020-07-23]

19. van Houwelingen CT, Ettema RG, Antonietti MG, Kort HS. Understanding older people's readiness for receiving telehealth: mixed-method study. J Med Internet Res 2018 Apr 06;20(4):e123 [FREE Full text] [doi: 10.2196/jmir.8407] [Medline: 29625950]

20. [White paper information and communications in Japan]. The Ministry of Internal Affairs and Communications, Japan. URL: https://www.soumu.go.jp/johotsusintokei/whitepaper/ja/h30/html/nd252120.html [accessed 2020-09-18]

21. [Verification of the results of telephone and online medical services from April to June 2020]. The Ministry of Health, Labour and Welfare, Japan. URL: https://www.mhlw.go.jp/content/10803000/000657020.pdf [accessed 2020-09-27]

\author{
Abbreviations \\ CRP: C-reactive protein \\ MHLW: Ministry of Health, Labor and Welfare \\ WBC: white blood cell
}

Edited by R Kukafka; submitted 17.08.20; peer-reviewed by A Taylor, E Donaghy, I Mircheva, CC Lin; comments to author 17.09.20;
revised version received 05.11.20; accepted 21.06.21; published 01.09.21
Please cite as:
Miyatake H, Kosaka M, Arita S, Tsunetoshi C, Masunaga H, Kotera Y, Nishikawa Y, Ozaki A, Beniya H
Videoconferencing for Home Care Delivery in Japan: Observational Study
J Med Internet Res 2021;23(9):e23539
URL: https://www.jmir.org/2021/9/e23539
doi: 1 10.2196/23539
PMID:

(CHirotomo Miyatake, Makoto Kosaka, Satoshi Arita, Chie Tsunetoshi, Hidehisa Masunaga, Yasuhiro Kotera, Yoshitaka Nishikawa, Akihiko Ozaki, Hiroyuki Beniya. Originally published in the Journal of Medical Internet Research (https://www.jmir.org), 01.09.2021. This is an open-access article distributed under the terms of the Creative Commons Attribution License (https://creativecommons.org/licenses/by/4.0/), which permits unrestricted use, distribution, and reproduction in any medium, provided the original work, first published in the Journal of Medical Internet Research, is properly cited. The complete bibliographic information, a link to the original publication on https://www.jmir.org/, as well as this copyright and license information must be included. 